\title{
BIDADARI-BIDADARI SURGA INTRINSIC ELEMENTS: A NOVEL ANALYSIS
}

\author{
Cendy Lauren \\ University of Lancang Kuning \\ Cendylauren7@gmail.com
}

\begin{abstract}
This study aims to describe the intrinsic elements of Tere Liye's Bidadari-bidadari Surga novels. The method used to obtain data in this study is a qualitative descriptive method. Sources of data are excerpts of words, sentences, and discourses found in the novel Bidadari-Bidadari Surga by Tere Liye published by Republika in 2008. Related to the intrinsic elements that build literary works from within, data collection is done by reading data sources and researchers act as instruments. The researcher identifies, classifies, and codifies the data based on the problems studied. The data collection technique of this research uses textual techniques. Data analysis was carried out in a qualitative descriptive manner by reading, identifying, interpreting, and interpreting the data then drawing conclusions. The results of the analysis of this study show that the Bidadari-Bidadari Heaven novels have the theme of kinship and characters who are hard-nosed, not open, willing to sacrifice, kind-hearted, naughty, obedient, not deterred, and hardworking from several figures in the story. This novel is worth reading by teenagers, adults, the elderly and the elderly because this novel has a moral value that is very close to society.
\end{abstract}

Keywords: intellectual element, moral value, character

\section{INTRODUCTION}

Literary works are created because of the author's inner experience of interesting social events or realities. this experience gave birth to the idea of imagination as outlined in writing. This means that something imaginative may occur in real life. Cloth people may experience the same event, as stated in the literary work. this is in line with Pradopo (1997) who argues that "more and more literary works emit a level of mental experience and are of high value, combined with the more complete experience, literary works become increasingly large, large and grand, so they become higher quality "(p. 59). The essence of a literary learning is the appreciation of literature because in the appreciation of literature students can meet directly with literature. Students carry out activities to read, enjoy, appreciate, understand, and respond to literature in front of the public. There was created a conducive climate so that students are more obsessed with literary work and the dynamics in it so students become interested in participating in this learning. Through the appreciation of literature students are expected to be able to appreciate and give sincere appreciation to existing literary works. One type of literary work is a novel. Novels as a work of fiction offer an imaginative world that is not much different from real human life. In novels it is usually possible to have a broad presentation of a place or space so it is not surprising that human existence in society is always the main topic. Novels as fictional works depict the reality of human life from the standpoint of literature. Fictional life will not be separated from the reflection of everyday social facts. These facts may be things that the author has seen, felt, experienced, and aspired to, usually reflected in his work. so, the novel combines the facts of the imagination and idealism of the author.

Today's novels with teenagers, love, and lots of sex appear in circulation. A theme that is so selling but less educating for readers in general. But of the many, there are still a number of novels that try not to be tempted by the theme and try to provide other themes that are nicely packaged to make a quality and quality reading. One of the novels, there is a novel that makes family as its theme. Has a neat storytelling style and the use of perspective and detailed settings that make it a novel that is good and worth reading. this novel is the angel of heaven by Tere Liye. Bidadari-Bidadari Surga is one of novels which the best-seller in Indonesia. The theme of the novel is about a Family. This novel which is full of the meaning of hard work, sacrifice and respect, was written by a novelist who was familiarly called by the name of the questioner Tere Liye. This novel is for adults and teenagers, but it is also readable for children with parental advice. Bidadari-Bidadari Surga by Tere Liye is published by Republika in Jakarta. The first copyright edition of the book was made in June 2008 and the thirteenth copyright edition was in February 2013. The length and the width of the book are 20,5 $\mathrm{cm} \times 13,5 \mathrm{~cm}$ with 368 pages and the ISBN is 978-979-1102-26-1.

By searching on idwriters.com it is known that Tere Liye or Darwis born in Kikim, Sout Sumatera (21th May 1979: 40 years old) and currently lives in Jakarta. He started writing in elementary school. He 
has a bachelor's degree from the Faculty of Economics, University of Indonesia, Depok. Beside writing, Tere Liye is also a Finance Professional. To this day, he has written not less then 21 books, ranging from novels, poetry collections and books of quotations. The fiction he writes varies, ranging from fantasy, action, children stories, family stories, religious stories, love stories, to historical novels. $\mathrm{He}$ also regularly writes columns on economics, politics and culture. His novels include Hafalan Shalat Delisa (2005), Rembulan Tenggelam di Wajahmu (2009), Daun yang Jatuh Tak Pernah Membenci Angin (2010), Eliana (serial anak-anak Mamak, Book 4, 2011), Negeri Para Bedebah (2012), and Dikatakan atau Tidak Dikatakan, Itu Tetap Cinta (2014). Several of his books have received literary awards. Negeri Para Bedebah and the poetry compilation Dikatakan atau Tidak Dikatakan Itu Tetap Cinta both won Indonesia Reader's Choice, negeri Para Bedebah wsa lso shortlisted for the Kuala Sastra Khatulistiwa and the novel Rindu Won Islamic Book Award. Three of his novels have been filmed, including his debut novel Hafalan Shalat Delisa, which became a blockbuster in 2011. Some of his novels have been made into television series, including Serial Anak Kaki Gunung, which received an award for television series at the Bandung Film Festival 2012.

\section{MATERIALS AND METHOD}

Qualitative research, trying to describe the object of research in the form of words in the BidadariBidadari Surga novels with a view to understanding phenomena holistically, by describing them in the form of words and languages, in a specific natural context and by utilizing various scientific methods (Moleong, 2005).

Qualitive descriptive used in this study also aims to make a description, description, or painting systematically, factually and accurately of the factors, traits and relationships between the phenomena investigated. Ie the side of morality in Bidadari-Bidadari Heaven novels by Tere Liye.

\section{RESULTS AND DISCUSSION}

\subsection{The STRENGTH OF THE NOVEL}

This book is very touching and inspiring, the story is very interesting. The story is reviewed in great detail and as if the reader feels what the writer tells.

\subsubsection{THEME}

Them is another strength in the novel. According to Abrams in Glossary of Literary Term $(1999 ; 169)$ "Theme is sometimes used interchangeably with "motif" but the term is more usefully applied to general concept ir doctrine, whether implicit or asserted, which an imaginative work is designed to incorporate and make persuasive to the reader". Family is theme that appears in the novel. The novel tells about the sacrifice of a brother (Laisa) to his siblings (Dalimunte, Ikanuri, Wibisana, and Yashnta). The theme is shown in the following quote:

"Kak Laisa berlari sekuat kakinya ke kampung atas. Tidak peduli tetes air hujan bagai kerikil batu yang ditembakkan dari atas. Tidak peduli tubuhnya basah-kuyup. Tidak peduli malam yang gelap gulita. Dingin membungkus hingga ujung kaki. Musim kemarau begini, di malam hari, suhu Lembah Lahambay bisa mencapai delapan derajat celcius. Kak Laisa berlarian menaiki lembah. Terpeselet. Sekali. Dua kali. Tidak peduli. Petir menyalak. Guntur. menggelegar. Ia ingat. Ia ingat kakak-kakak mahasiswa tadi menyebut-nyebut soal obat dan dokter. Mereka pasti bisa membantu.” (P. 66-67).

\subsubsection{CHARACTER}

\subsubsection{Laisa}

Laisa, the eldest child of mamak Lainuri. Laisa has dreadlocks, black skin, and short and fat body. While her sisters were beautiful and handsome, tall, white, and had straight hair. Character:

\section{(a) Hard and cruel}

This character can be seen from the attitude of Kak Lais when he learned that Dalimunte skipped school, then hit Dalimunte using a tree branch. 
"Kak Laisa menukas tajam, tangkas menyambar ranting yang kebetulan hanyut di dekat kakikaki mereka, dan tentu saja ranting itu gunanya buat menunjuk-nunjuk dada Dalimunte. "Sejak kapan kau berani bolos sekolah, hah?" Kak Laisa menghardik." (P. 24)

\section{(b) Willing to sacrifice}

This can be seen from the attitude of Sis Laisa who chose to quit school to help other Mamakas find money so that their younger siblings could continue their studies.

“Tidak. Kak Lais keliru. Dali mengerti benar. Mamak sudah bekerja keras demi mereka. Mengerti benar Kak Laisa mengorbankan seluruh masa kanak-kanak dan remajanya agar bisa membantu Mamak setiap hari tanpa lelah demi adik-adiknya sekolah. Dalimunte menyeka matanya. Menangis, rusukan ranting Kak Laisa di dada terasa sakit sekali, tapi hatinya lebih sakit lagi. Sungguh dia tidak bolos demi sesuatu yang percuma. Dia tidak sedang main air. Tapi dia tidak bisa menjelaskannya" (P. 25)

\subsubsection{Dalimunte}

Dalimunte is the second child of Mamak Lainuri. A physics professor whose name is already famous. Character:

\section{(a) Brave}

This can be seen from the incident when Dalimunte dared to submit a proposal to make a waterwheel at a routine meeting of the Lahambay Valley residents, even though he was still small, as quoted:

"MAKSUDMU, kita bisa mengangkat air sungai itu dengan kincir-kincir itu, Dali?" Salah seorang pemuda bertanya, memecah lengang setelah Dalimunte selesai menunjukkan gambar-gambarnya. Dalimunte mengangguk mantap. "Lantas membuatnya mengairi ladang-ladang kita?" Bertanya lagi. Sedikit terpesona, lebih banyak sangsinya. Dalimunte mengangguk sekali lagi. Bahkan kincir-kincir itu bisa sekalian digunakan sebagai pembangkit listrik. "Itu lima meter tingginya, Dalimunte! Sebesar apa kincir yang harus kita buat agar bisa mengangkat air dari sungai bawah cadas? Kau harusnya tahu itu." Pemuda itu berseru sedikit putus-asa. "Tidak besar. Tidak besar!" Dalimunte menjawab cepat. Setelah lima menit menjelaskan kertas-kertasnya dengan terbata-bata, meski masih gugup, dia jauh lebih tenang sekarang, "Tapi kita akan membuat lima kincir air, membuatnya bertingkat! Tidak besar!" (P . 34)

(b) Obedient

This can be seen from the attitude of Dalimunte who never refused Sis Laisa's orders.

"Kau tahu! Mamak setiap hari ke ladang! Setiap sore ke hutan mencari damar! Mengumpulkan uang sepeser demi sepeser agar kalian bisa sekolah! Lantas apa yang kau berikan sebagai rasa terima kasih? BOLOS SEKOLAH!! BERMAIN AIR??" Dalimunte tertunduk dalam-dalam. Menyeka matanya yang tiba-tiba panas, berair. Dali tidak sedang bermain air, Kak Lais. Sungguh — "KAU BENAR-BENAR TIDAK TAHU MALU! MAU JADI APA KAU KALAU BESAR NANTI??" Tidak. Kak Lais keliru. Dali mengerti benar. Mamak sudah bekerja keras demi mereka. Mengerti benar Kak Laisa mengorbankan seluruh masa kanak-kanak dan remajanya agar bisa membantu Mamak setiap hari tanpa lelah demi adik-adiknya sekolah. Dalimunte menyeka matanya. Menangis, rusukan ranting Kak Laisa di dada terasa sakit sekali, tapi hatinya lebih sakit lagi. Sungguh dia tidak bolos demi sesuatu yang percuma. Dia tidak sedang main air. Tapi dia tidak bisa menjelaskannya. "KAU DENGAR KATAKU?!" Dalimunte terisak, mengangguk. "PULANG! PULANG SANA!!" Kak Laisa keras memukul lengan Dalimunte dengan ranting. Yang dipukul menyeka hidungnya yang kedat. Sakit. Tangannya terasa pedas, perih. Tapi hatinya tertusuk lebih sakit. Dia tahu. Tentu saja dia tahu, Dalimunte melangkah pelan, menyusuri inang sungai" (P. 25) 


\title{
(c) Sensitive to the environment
}

It was known from his reaction that he knew the fields in his village only relied on rain, he then made a water mill.

"ANAK KECIL berumur dua belas tahun itu sedang sibuk menyusun balok-balok bambu di pinggir sungai yang mengalir deras. Mukanya serius. Mulutnya sedikit terbuka. Kepalanya terus berpikir. Sekali, dua kali, tiga kali, berkali-kali, dia menyusun ulang balok-balok itu. Jatuh, disusun kembali. Gesit. Terampil tangannya mengikatkan tali rotan. Memukul ujung bambu dengan batu agar melesak lebih dalam ke tepi sungai. Cahaya matahari pagi yang meninggi menyinari Wajahnya. Herhenti sejenak. Menyeka keringat. Lantas beranjak ke tepi sungai. Mengambil kincir yang tersandar di cadas batu setinggi lima meter. Kincir dari batang bambu itu benar-benar seadanya. Jauh dari kokoh. Tapi itulah usaha terbaiknya. Sudah seminggu terakhir dia sembunyi-sembunyi membuatnya. Selepas pulang sekolah. Selepas membantu Mamak Lainuri dan Kak Laisa di ladang. Kapan saja ada waktu luang. Dia akan berlari ke tubir cadas sungai. Mengerjakan proyek rahasianya jadi bagaimanalah akan kokoh dan baik bentuknya" (P.23)

\subsubsection{Ikanuri}

Is the third child of Mamak Lainuri. Character:

\section{(a) Naughty} school.

This can be proven when Ikanuri and Wibisana steal mango and the habit of those who often skip

"Laisa mendekat. Menyelidik. Menatap tajam pohon mangga yang sedang ranumranumnya berbuah. Daunnya yang rimbun seperti dipenuhi benjol-benjol buah yang besarbesar. Dahan pohon itu bergoyang-goyang lagi. Laisa melangkah semakin cepat. Tinggal sepelemparan batu, tinggal lima belas meter, akhirnya ia bisa melihat bayangan yang membuat pohon itu bergerak. "Cepat, Ikanuri-" Berbisik tertahan. "Sebentar." Suara itu ikut tertahan. "Kak Laisa! Ada Kak Laisa! Cepat turun..." "Sebentar, celanaku tersangkut - " GEDEBUK! Ikanuri yang bergegas turun dari pohon mangga malah terjatuh, kehilangan keseimbang saat buru-buru, menimpa Wibisana yang sudah turun duluan. Tidak tinggi benar, hanya satu meter, karena mereka sudah tiba di dahan terendah. Tapi itu membuat pelarian mereka gagal total. Ikanuri yang sibuk mengaduh selama lima detik, memberikan waktu yang cukup bagi Laisa untuk mengenali siapa. "IKANURI! WIBISANA!" (P.41)

\section{(b) Disobedient}

It was proven by the attitude of Ikanuri who never followed Sis Laisa's orders when she was little.

\begin{abstract}
"Kalau kau bolos, berarti Ikanuri dan Wibisana juga bolos!" Kak Laisa bertanya menyelidik, menusuk dadanya lebih keras. Dalimunte meringis. Soal itu tidak usah ditanya lagi, meski ada Kak Laisa sekalipun Ikanuri dan Wibisana rajin bolos, apalagi jika Kak Laisa tidak ada. Lebih berani melawan. Tadi pagi sih mereka bertiga pamitan ke Mamak, memakai seragam, menuju sekolah di desa atas. Tapi baru tiba di pertigaan jalan bebatuan selebar tiga meter itu, Ikanuri dan Wibisana sudah kabur duluan, naik starwagoon tua yang kebetulan lewat ke kota kecamatan. Dalimunte sebenamya jauh lebih nurut. Dia meski terkadang bosan sekolah, tapi tidak pernah membolos. Tadi pagi saja, butuh waktu sepuluh menit di pertigaan itu hingga akhirnya dia berani memutuskan untuk ikut membolos. Menyelesaikan kincir airnya. " (P.24)
\end{abstract}

\subsubsection{Wibisana}

The fourth child of Mamak Lainuri who has a face similar to Ikanuri, but not a twin of Ikanuri. They were born in the same year, only eleven months apart. Wibisana has the exact same character as Ikanuri, because Wibisana also did whatever the fishuri did. 


\subsubsection{Yashinta}

The last child of Mamak Lainuri who likes animals and adventures. Having a stubborn character described by the author when Yashinta repeatedly refused Sis Laisa's orders to marry Goghsky. And it has proven indifferent character when Yashinta answers with short answers, Goghsky's question.

\subsubsection{Mamak Lainuri}

\section{(a) Kind-hearted}

It was proven by the willingness of Mamak Lainuri to treat Laisa, even though it was not her biological child.

"PULANGLAH. Sakit kakak kalian semakin parah. Dokter bilang mungkin minggu depan, mungkin besok pagi, boleh jadi pula nanti malam. Benar-benar tidak ada waktu lagi. Anak anakku, sebelum semuanya terlambat, pulanglah...." Wajah keriput nan tua itu menghela nafas. Sekali. Dua kali. Lebih panjang. Lebih berat. Membaca pesan itu entah untuk berapa kali lagi. Pelan menyeka pipinya yang berlinang, juga lembut menyeka dahi putri sulungnya, wanita berwajah pucat yang terbaring lemah di hadapannya. Mengangguk. Berbisik lembut: "Ijinkan, Mamak mengirimkannya, Lais.... Mamak mohon...." Pagi indah datang di lembah itu. Cahaya matahari mengambang di antara kabut. Embun menggelayut di dedaunan strawberry. Buahnya yang beranjak ranum nan memerah. Hamparan perkebunan strawberry terlihat indah terbungkus selimut putih sejauh mata memandang. Satu bilur air mata akhirnya ikut menetes dari wanita berwajah redup yang terbaring tak berdaya di atas tempat tidur. Mereka berdua bersitatap satu sama lain, lamat-lamat. Lima belas detik senyap. Hanya desau angin lembah menelisik daun jendela. Ya Allah, sungguh sejak kecil ia menyimpan semuanya sendirian. Sungguh. Demi adik-adiknya. Demi kehidupan mereka yang lebih baik. Ia rela melakukannya. Tapi, sepertinya semua sudah usai. Waktunya sudah selesai. Tidak lama lagi.” (P.2)

\subsubsection{PLOT}

This novel has a mixed groove (back and forth forward). In the C.1 P.2 with the title Four Corners, here shows the forward path as quoted:

"Empat nomor telepon genggam! Tak peduli di manapun itu berada. Tak peduli sedang apapun pemiliknya. Kabar itu segera terkirimkan. Melesat mencari empat nomor telepon genggam yang dituju." (P. 02).

But in the C.2 P.8 with the title Split Moon at the end of the story, here shows the backward flow as quoted:

"Sedikit terburu-buru meraih telepon genggam. SMS. Kenapa harus dengan SMS? Jika penting bukankah bisa langsung menelepon? Itu berarti Mamak Lainuri yang mengirimkan. Mamak tak pandai benar berbicara lewat HP, selalu merasa aneh. Setetah terdiam sejenak menatap layar HP, Dalimunte gemetar menekan tombol open. SMS itu terbuka. Gagap membaca kalimatnya. Menggigit bibir. Menyeka dahi yang berkeringat. Terdiam lagi satu detik. Dua detik. Lima detik. Lantas dengan suara amat lemah berkata pendek di depan speaker. "Maaf. Cukup sampai di sini- "." (P. 08)

\subsubsection{VALUE}

The religious value of the novel is devotion to God the Almighty. The social value of the novel is mutual help, respect, and love. Moral values in novels are devotion to parents and older people.

We can also take the lessons contained in it about God's destiny, that life, soul mate, sustenance, and death are entirely God's. Humans can only try their best and pray, but the final decision remains in God's hands. 


\subsection{THE WEAKNESS OF THE NOVEL}

\subsubsection{LANGUAGE STYLE}

This novel is compiled with a bandage of dialogues that are quite successful in making the emotions of the readers explore the feelings of the characters in it.

"Aku harus pulang, Dok. Tidak ada pilihan lain. Besok Ikanuri dan Wibisana menikah, bagaimana mungkin aku tidak di sana?" (P. 108)

"Ya Allah, aku mohon, meski hamba begitu jauh dari wanita-wanita mulia pilihanmu, hamba mohon kokohkanlah kaki Laisa seperti kaki Bunda Hajra saat berlarian dari SafaMarwa.... Kuatkanlah kaki Laisa seperti kaki Bunda Hajra demi anaknya Ismail.... Mereka tidak boleh melihat aku sakit..." (P. 108)

However, the language style in this novel is rather confusing, for example, to lay out a way to call key characters, sometimes called Sis, sometimes called Wawak, in some places it is a bit messy. As quoted:

"Mereka lagi-lagi berisik saat naik ke rumah panggung. Ribut soal siapa yang duluan salaman dengan Eyang Lainuri dan Wawak Laisa. Saling dorong saat masuk kamar. Tidak mempedulikan tatapan tetangga yang sedang mengaji yasin. Tetapi dua sigung kecil itu seketika terdiam saat melihat ke dalam kamar." (P. 80)

\subsubsection{ENDING OF THE NOVEL}

This novel that feels a little awkward is about the author's point of view. There is confusion on the position of the author in this story sometimes there is no correlation with the storyline. Like the quote in the story:

"Aku akan selalu mencintaimu, Yash." Berbisik, meyakinkan. Yashinta tertunduk. Menggigit bibir. "Menikahlah, Yash-" Kak Laisa tersenyum. Dan Yashinta gemetar mengangguk. Cahaya matahari senja menerabas indah bingkai jendela kamar. Berpendarpendar jingga. Sungguh senja itu wajah Kak Laisa terlihat begitu bahagia. Mungkin seperti itulah wajah bidadari surga. Lima menit kemudian pernikahan itu dilangsungkan. Dalimunte yang menjadi wali pernikahan. Bang Jogar dan salah satu penduduk kampung lainnya menjadi saksi.

Pernikahan terakhir di lembah indah mereka. Seusai Goughsky mengucap ijab-kabul. Saat Yashinta menangis tersedu. Ketika Mamak menciumi kening bungsunya memberikan kecupan selamat. Saat yang lain buncah oleh perasaan entahlah. Semua perasaan ini.... Saat itulah cahaya indah memesona itu turun membungkus lembah. Sekali lagi. Seperti sejuta pelangi jika kalian bisa melihatnya. Di sambut lenguhan penguasa Gunung Kendeng yang terdengar di kejauhan. Kelepak elang yang melengking sedih. Bagai parade sejuta kupukupu bersayap kaca. Menerobos atap rumah, turun dari langit-langit kamar, lantas mengambang di atas ranjang. Lembut menjemput. Kak Laisa tersenyum untuk selamanya. Kembali. Senja itu, seorang bidadari sudah kembali di tempat terbaiknya Bergabung dengan bidadari-bidadari surga lainnya.

Dan sungguh di surga ada bidadari-bidadari bermata jeli (Al Waqiah: 22). Pelupuk mata bidadari-bidadari itu selalu berkedip-kedip bagaikan sayap burung indah. Mereka baik lagi cantik jelita. (Ar Rahman: 70). Suara Mamak berkata lembut saat kisah itu diceritakan pertama kali terngiang di langit-langit ruangan: bidadari-bidadari surga, seolah-olah adalah telur yang tersimpan dengan baik (Ash-Shaffat: 49)" (P. 136)

\section{CONCLUSION}

Based on the results of the data analysis that the author has described, then conclusions can be taken as follows: The themes, settings, characters, and mandates of the Bidadari-bidadari heaven novels are the advantages of the novel. Where the family theme raised by the author is common in the surrounding community. And overall this story in this novel, really this is a novel that is very beautiful, touching, and full of life learning. Tere Liye with his words were light, easy to understand, and sometimes tickled again and again anesthetized his readers so that they could flow in every incident. It's a story of struggle that is so moving. Give lessons and remind the reader of the meaning of hard work, 
compassion, and sincerity. The figure of laisa is a marvelous reflection of man. A human figure who still does good and tries to benefit others. Even he didn't have time to think about himself. This is happiness and sincerity of essential love. In this story Laisa gives a message that happiness is when you can see other people happy. Therefore, this novel is very worth reading by all people, especially those who want to understand the true meaning of love, affection and struggle for life.

\section{REFERENCES}

Endraswara, S. (2003). Metodologi Penelitian Sastra (Epistimologi, Model, Teori, dan Aplikasi). Yogyakarta: Pustaka Widyatama.

Hamuddin, B. (2016). Using Content Analysis (CA) in Seeking the Opportunities for Alumni of English Department in Newspapers. ELT-Lectura, 3(1).

Liye, T. (2008). Bidadari-bidadari Surga. Jakarta: Replubika.

Miles, B.M dan Huberman, M. (1992). Analisis data Kualitatif. (Terjemahan Tjeptjep Rohendi Rohidi). Jakarta: UI Press

Moleong, J.L. (2000). Metodologi Penelitian Kualitatif. Bandung: PT. Remaja Rodakarya.

Nurgiyantoro, B. (2005). Teori Pengkajian Fiksi. Yogyakarta: Gadjah University Press.

Sangidu. (2004). Penelitian Sastra: Pendekatan, Teori, Metode, Teknik dan Kiat. Yogyakarta: Unit Penerbitan Sastra Asia Barat Fakultas Ilmu Budaya Universitas Gadjah Mada.

Sari, R., Putri, S. E., Herdi, H., \& Hamuddin, B. (2018). BRIDGING CRITICAL DISCOURSE ANALYSIS IN MEDIA DISCOURSE STUDIES. Indonesian EFL Journal, 4(2), 80-89.

Semi, M.A. (1993). Anatomi Sastra. Padang: Angkasa Raya.

Tarigan, H.G. (1984). Prisip-prinsip Dasar Sastra. Bandung: Angkasa. 
